\title{
Soils and Human Creation in The Holy Quran from The Point of View of Soil Science
}

\author{
Hassan El-Ramady ${ }^{1}$, Tarek Alshaal ${ }^{1}$, Alaa El-Dein Omara ${ }^{2}$, Tamer Elsakhawy ${ }^{2}$ \\ and Zakaria F. Fawzy ${ }^{3}$ \\ ${ }^{1}$ Soil and Water Dept., Faculty of Agriculture, Kafrelsheikh Uni., Egypt (E-mail: \\ alshaaltarek@gmail.com) \\ ${ }^{2}$ Agricultural Microbiology Dept., Soil, Water and Environment Research Institute \\ (SWERI), Sakha Agricultural Research Station, Agriculture Research Center (ARC), \\ Egypt (E-mail: alaa.omara@yahoo.com; drelsakhawyg@gmail.com) \\ ${ }^{3}$ Vegetable crops Dept., Agriculture and Biological Research Division, National \\ Research Centre, Egypt (E-mail: zakaria6eg@gmail.com)
}

$\mathbf{T}$ HERE is no doubt that the universe is totally controlled by the Great Creator (God or Allah). Allah created everything in this universe, from humans (Man) to animals, plants, soils, air, water, etc., where everything was made or created from water. Concerning the creation of humans, Allah created or made all things in an excellent phase and the first step of human creation was fashioned from clay. These steps include the creation of Man from spurting water, a drop of semen, the sperm fashioned into an embryo, this embryo fashioned into a shapeless lump of flesh, then from the lump of flesh, fashioned bones, then clothed the bones with flesh and then created the consanguinity and affinity. So, a very strong link between soil and human health has been reported and the great roles of soils in plant and human nutrition have also have been established. On the other hand, the effect of pollution of soils and their security on human health should be considered. Therefore, this review is an attempt to emphasize the great roles of soils in human creation and health as well as the security of soils under pollution conditions.

Keywords: Humans, Clay, Soils, Pollution, Soil security, Ecosystem services.

\section{Introduction}

Soils and humans were and still are one of the most important relationships, and scientists are seeking new approaches and facts in this area (Brevik and Burgess 2012, 2014; Winiwarter 2014; Brevik and Sauer 2015; Brevik et al. 2017; Carré et al. 2017). This interaction between soils and humans includes many fields or issues such as (1) the role of soil in human emergence or creation, (2) its role in plant and human nutrition or biofortification, (3) its role in human health and (4) the role of this interaction in soil security. Definitely, plant and human nutrition mainly depends on soils and their status. In other words, sufficient plant nutrition is important for proper and safe human health. As mentioned in the following verse (Ayah 55) in the Holy Quran in Surah (Chapter) Taha:

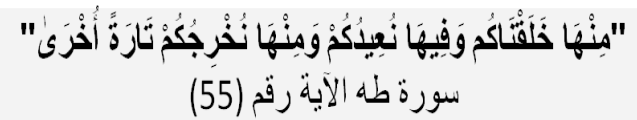

That means "God created the Man from the soil and this Man will be reverted back into this soil after death and then God will raise him up from it a second time". This can be proven through the elements or nutrients that are found in soil, plants and humans, including carbon, nitrogen, phosphorus, potassium; these elements are present in and beneficial to all. Only 11 elements constitute nearly $99.9 \%$ of the human body (as atoms) including the major elements $(\mathrm{C}, \mathrm{H}, \mathrm{O}$ and $\mathrm{N})$ that represent $99 \%$ and minor elements $(\mathrm{P}, \mathrm{K}, \mathrm{Ca}$, $\mathrm{Mg}, \mathrm{S}, \mathrm{Na}$ and $\mathrm{Cl}$ ) that represent $0.9 \%$ of the body (Combs 2005). With the exception of C, H, and O these elements come from the soil. Therefore, a strong interdependence between humans and soil exists. The history of human civilization is based mainly on the strong relationship between soil and humans as well as the influence of humans on soil quality, and humans' perception of how to manage soil resources (Lal 2005).

Therefore, this review will focus on the role of soils in the creation of humans, their influence on proper human health, including diseases, supplying nutrition for both plants and humans and soil security as it relates to human health.

*Corresponding author e-mail: ramady2000@gmail.com DOI:10.21608/jenvbs.2019.7856.1052

C2017 National Information and Documentation Center (NIDOC) 
These issues are very important in human health and maintaining the security of all our lives.

\section{Soil as a Real Treasure}

Soil is the important surface layer of the Earth's crust, in which plant roots can grow and develop (Fig. 1). An important subdivision of this layer is the rhizosphere, which plays a key role as a medium for plant growth and its nutrition. So, the rhizosphere is at the heart of our understanding of soil. This rhizosphere includes soil organic matter, minerals, gases, liquids or soil solution, and organisms, which together support life. Soil science is the science that deals with all disciplines of soil and its properties including soil physics, chemistry, biology, mineralogy, etc. Soil is also commonly referred to as earth or dirt. Recent trends in soil sciences have led to a proliferation of studies that confirmed the importance of soil for agroecosystems (e.g., Lizaga et al. 2019; Ondrasek et al. 2019), human health (e.g., Brevik et al. 2018, 2019) and sustainability (Pereira et al. 2018; Meena et al. 2019).
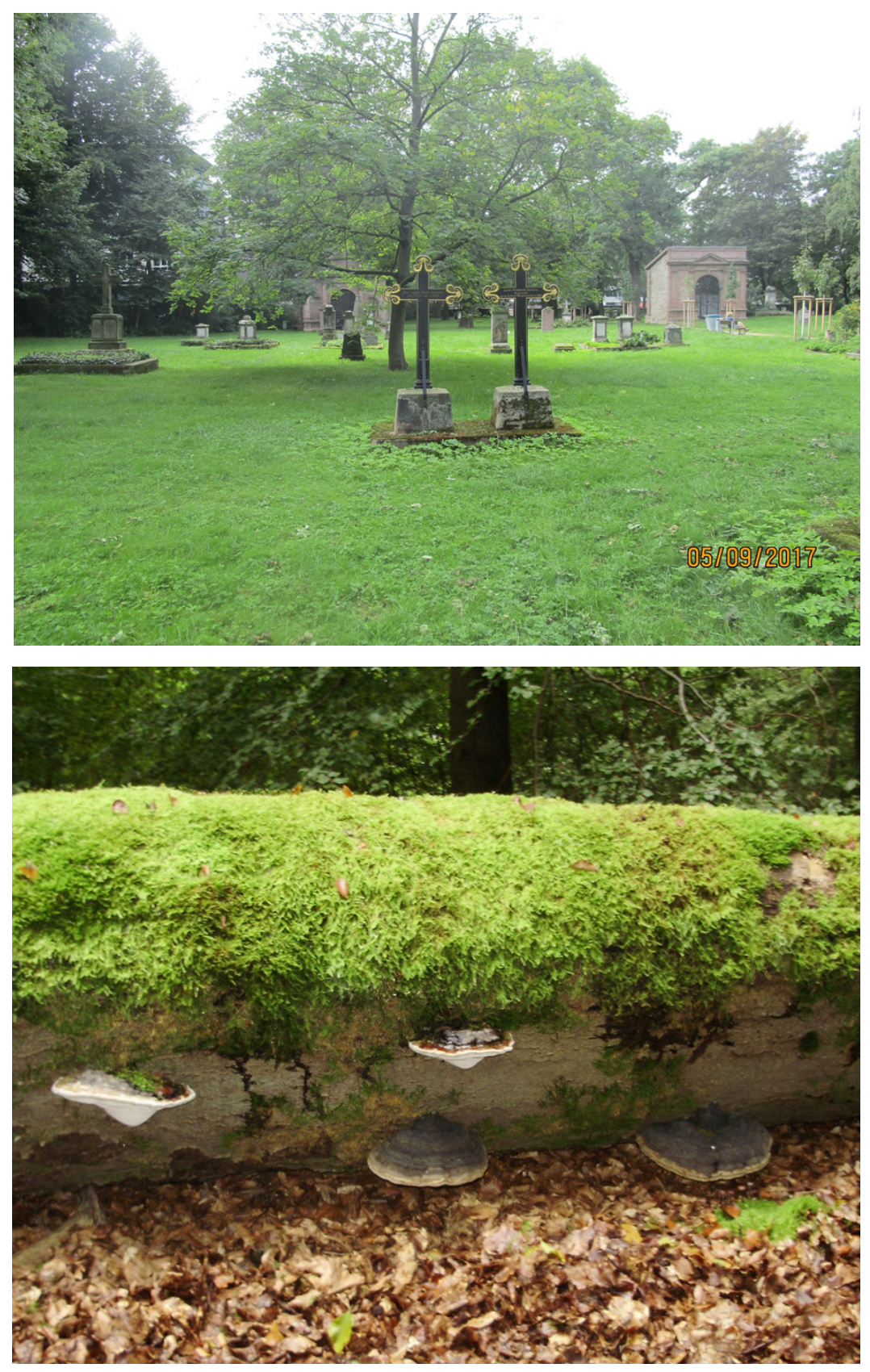

Env. Biodiv. Soil Security Vol. 3 (2019) 

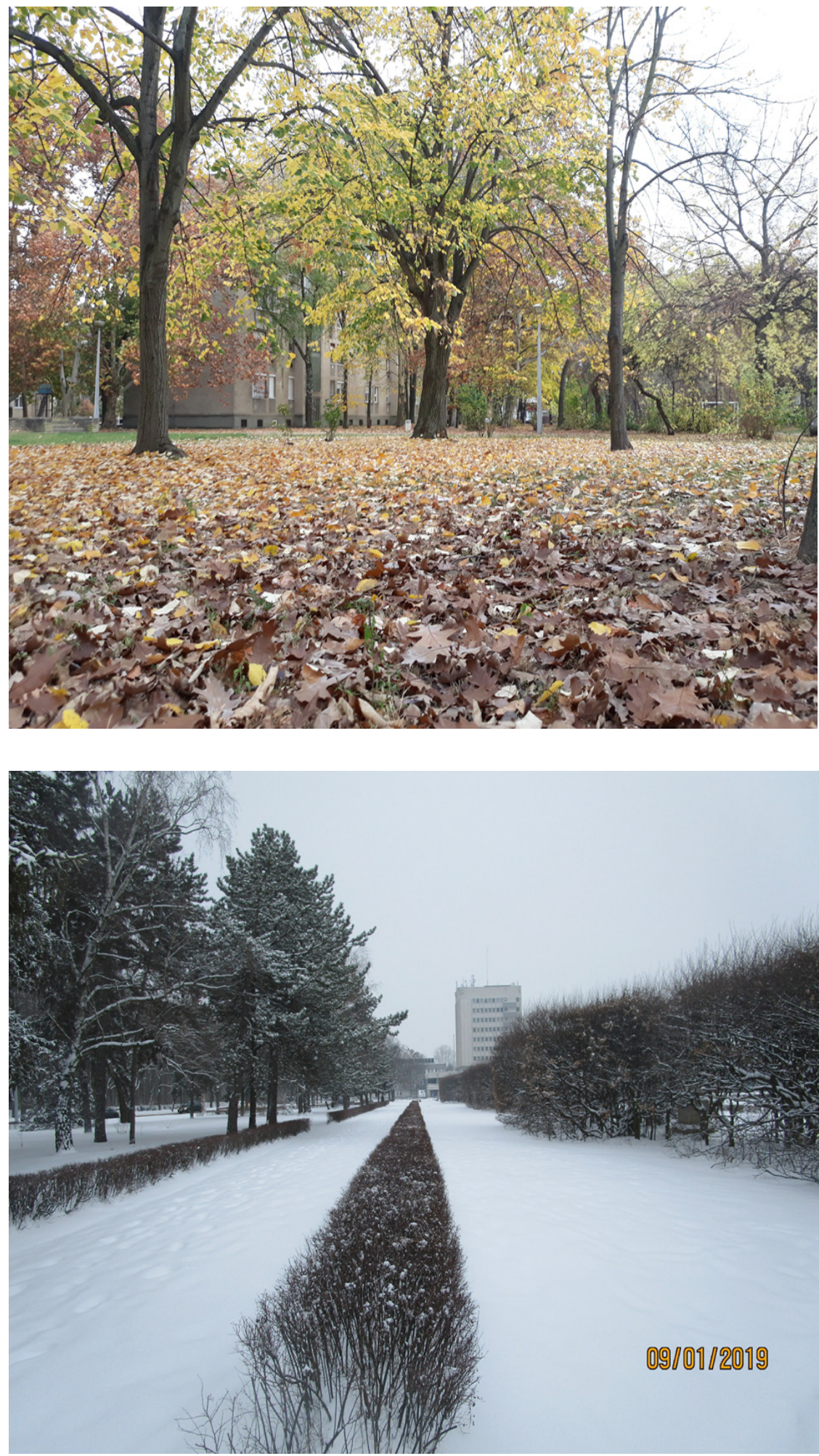

Fig. 1. The soil can be created depending on some factors, these factors called soil forming factors including parent material, topography, organism, climate and time. The last two factors can be distinguished through the photos including the summer, autumn and winter season (Photos by El-Ramady from Germany (the first 2 photos) and Hungary (the last 2 photos). 
Recently, a considerable literature has grown up around the theme of the soil as real treasure (e.g., Alshaal et al. 2019; El-Ramady et al. 2019). Many aspects of soil have long been of great interest in a wide range of agricultural fields including soil organic carbon, soil water storage capacity, and soil microorganisms. Numerous attributes of soil vital to essential ecosystem services are hidden beneath the surface, and are neither obvious to a casual observer nor easily comprehended (Baveye et al. 2016). These ecosystem services are an important aspect of soil and its function. Recently, there has been strong interest in the ecosystem services provided by soils (e.g., Andrea et al. 2018; Brevik et al. 2018; Pavan and Ometto 2018; Pereira et al. 2018; Baude et al. 2019; La Notte et al. 2019). It has been suggested that ecosystem services could be defined as the indirect and direct contributions of ecosystems to human well-being. These services include (1) regulation of flood and erosion processes, (2) provision of food and water and (3) soil formation and non-material benefits such as recreation (Pavan and Ometto 2018). These services also emphasize that soils are an important source of human shelter, clothing, and fuel, which are linked to human health (Brevik et al. 2019). Therefore, soil is the main source for our food, feed, fuel and fiber and links between ecosystem services, soils and human health should not be overlooked.

What we know about soils is largely based on field and laboratory studies. Due to misuse or neglect by humans, soil and water resources are one of the most rapidly declining and degrading in our ecosystem. Therefore, several environmental problems have arisen in the $21^{\text {st }}$ century including pollution, eutrophication, salinization and others (Singh 2019). Furthermore, the pollution of soil and water is a major public health problem, and the main cause of this pollution should be managed. There is an urgent need to address the safety problems caused by this pollution. This pollution also has led to the declines in the populations of soil macro- and micro-organisms (i.e., bacteria, protozoa and fungi) (Tecon and Or 2017). These organisms are essential to recycling biomass and are source of antibiotics and other services in soils. In light of recent events in soil science, it is becoming extremely difficult to ignore the existence of global problems for soils. Therefore, soil should be considered a great treasure should be conserved and maintained. The soil science community, including researchers, teachers, and communicators, has the challenging task of

Env. Biodiv. Soil Security Vol. 3 (2019) enhancing awareness about the importance of soil to human wellbeing and nature conservancy.

\section{Soils and Nutrition of Plants and Humans}

Soils are the main pool for essential nutrients and the growth medium for plants. These nutrients are also essential for the nutrition of animals as well as humans. Soils are the substrate for biogeo-physical and biogeo-chemical processes and are the unique natural organization forming the foundation of any water-energy -food nexus system. It forms a habitat for billions of diverse micro-, meso-, and macro-fauna and flora and is the basis of numerous ecosystem services essential to human well-being and nature conservancy. Soils and their properties control the bioavailability and release of essential nutrients for cultivated plants. Therefore, the health of humans starts with soils and their content of different nutrients that are used in human nutrition. Furthermore, it is very important to assess the biogeochemical behavior of these nutrients in the soil-plant system with respect to applied levels and speciation, which ultimately affect nutrient status in humans. Hence, further investigations are needed concerning the following issues for a rational link between (1) the sources and levels of nutrients, speciation, and bioavailability, (2) the role of different protein transporters in soil-root-shoot transfer of nutrients and (3) the metabolism, speciation, phytotoxicity and detoxification of nutrients inside plants. There is a new approach in dealing with the relationship between soils and human health worldwide (e.g., Balks and Zabowski 2016; El-Ramady et al. 2019; Brevik et al. 2018, 2019). This approach already has been listed among the main topics in the World Congress of Soil Science (WCSS21; Rio de Janeiro, Brazil, August 12-17, 2018), where a session C 4.2.1 (Soil and Human Health) was held. More than 7500 participants were be expected to attend during this congress (Lal et al. 2017; Natasha et al. 2018; Nieder et al. 2018 a,b).

\section{The Nexus of Soils, Plants and Humans}

Soil is an important component of the ecosystem and plays a key role indirect impacts on the health of humans through biogeochemical transformations and the flux of nutrients in mineral, liquid, gaseous and biological components. Indirect effects of soils on public health also result from many issues like climate change or global warming, catastrophic events such as flooding, droughts, heat and cold waves, and soil degradation, and exposure to natural or anthropogenic soil-borne compounds, and 
biological materials in soils. These direct effects could transfer to humans by various means such as consumption of plant and animal products, drinking water/beverages and air (inhalation) or skin exposure (Nieder et al. 2018a).

More than 16 elements are known to be essential for animals and plants (i.e., nitrogen, phosphorus, potassium, calcium, magnesium, sulphur and micronutrients) as reported by several researchers (e.g., Kathpalia and Bhatla 2018). The human body acquires these essential nutrients from plant and animal foods because it cannot biosynthesize them. Plants can uptake all essential nutrients from soils except for carbon, hydrogen and oxygen, which are obtained from air and water (Nieder et al. 2018b). The availability and utilization of nutrients impact human health through the provision of plant and animal foods in proper quantity and quality to meet the dietary requirements and food preferences of people. The essential nutrients are the main component of structural constituents of the human body including bones, teeth and cell walls as well as biomolecules (i.e., proteins, amino acids, enzymes, vitamins, hormones etc.) in order to perform several physiological functions (Nieder et al. 2018b).

It is worth mentioning that their several nexuses could be distinguished in agroecosystems including the soil-water-plant-energy, soilwater-food-energy, soil-water-food-energyclimate, water - food - energy, and soil - plant - human nexuses. Therefore, the health of soils, plants, animals, humans and ecosystems is one and indivisible. Consequently, soils are not only the main source for securing water, food, and energy as natural resources, but there is a desperate need to integrate and appreciate the contributions of soils in understanding the complex interconnectedness of any food, energy, and water system (Lal et al. 2017; Sullivan 2017). The nexus approach began in 2011 (Hanlon et al. 2013) with the Soil-WaterWaste nexus program at Dresden, Germany (Lal 2013a,b) and the launching of the Water-EnergyFood nexus initiative at Texas A \& M University in 2015. This twenty-first century approach is also attributed to the growing demands for finite resources (Lal et al. 2017).

\section{Soils and Human Creation}

Concerning the Holy Quran, it is the book of divine guidance and direction for humanity and the central religious text of Islam, which is the verbatim word of Allah. It is divided into 114 chapters (Surah) and 6,236 verses (Ayah). It is well known that there is no machine in the world more complicated than the human body. Muslims consider the creation of this body to be a great property of our God (Allah) as established in the Quran 1440 years ago. This creation started with clay, semen and finally creation of Man. For more details, the Holy Quran mentioned these periods or stages of human creation in different verses such as:

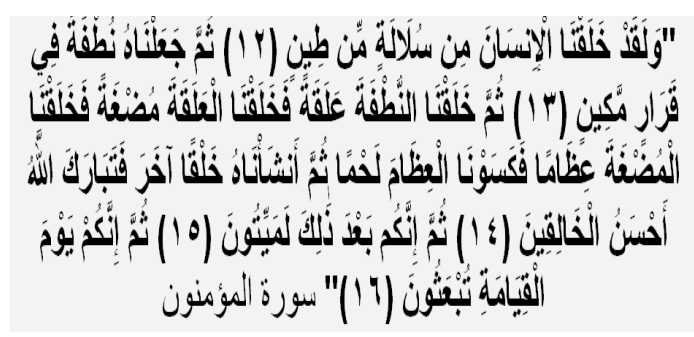

The meaning of the previous Ayahs is explained from the translation as given at the web site http:// www.alawfa.com, which translates and interprets the meaning of the Quran into different languages. Regarding the translation of the previous Arabic verses, God says:

"We created man from the finest extract of clay, then We placed him as a sperm in a firmly established lodging, then We fashioned the sperm into an embryo, then fashioned the embryo into a shapeless lump offlesh; then from the lump offlesh We fashioned bones, then clothed the bones with flesh. Thus We formed him into a new creation. So blessed be God the best of Creators, and then you will certainly die, and then will be raised up on the Day of Resurrection" Surah Al-Mo'menon (the Believers), verses 12 to 16 .

Concerning these previous verses, modern science has recently proved these steps of human creation. That means soil is definitely the main origin of human creation as a source for the elements that make up the human body. Therefore, the potential of soils should be considered by all people. God says in several places in the Quran that He (Allah) is the only one creator of the entire universe including humans, animals, plants, heavens, soils, air, water, the sun, and everything in the universe. This is summarized by some figures from the Quran concerning the relationships between soils and human creation as follows:

(1)The word "creation" is mentioned 83 times in the Quran, indicating that the creation of humans and all creatures was a great job of Allah.

Env. Biodiv. Soil Security Vol. 3 (2019) 
(2) The word "soil" is mentioned 287 times in the Quran, including different roles of soils in human life such as creation of humans, supporting humans with essential life needs (food, feed, fiber and fuel), etc.

(3) The word "soil" is mentioned with different meanings; soil may be used as a meaning for clay, land, earth, or the universe with certain and very precise uses in each verse.

(4) The following verse is just one example regarding the creation of humans and the capability of God (the great Creator) to create heaven, the earth, the night, the day and everything. As mentioned in the Quran: "Verily, all things, We have created by measure" in Sura Al-Qamar (The Moon), Ayah 49. In another verse, God says:



The translation for the previous verse (Ayah) includes the following meaning: "Creation of the heavens and the earth, alternation of night and day, and sailing of ships across the ocean with what is useful to man, and the rain that God sends from the sky enlivening the soil that was dead, and the scattering of beasts of all kinds upon it, and the changing of the winds, and the clouds which remain obedient between earth and sky, are surely signs for the wise" Surah Al-Baqarah, Ayah (164).

(5) All living things or creatures are created from the water as God says: "We made every living thing from water" Surah Al-Anbiya, Ayah (30). That means the creation of human from soil includes several reactions or steps as mentioned in Surah the Believers in a very close relationship to water as mentioned in several verses in the Quran such as:

"It is He who created man from water, then gave him consanguinity and affinity. Your Lord is omnipotent" Surah Al-Furqan, verse no. (54).

"There is a sign in the dead soil for them which We quicken, and produce from it grain which they eat" Surah Yaseen, verse no. (33).

"It is among His signs that the soil you see all barren and desolate begins to stir and sprout

Env. Biodiv. Soil Security Vol. 3 (2019) when We send down rain upon it. Surely He who gives it life will also give life to the dead. Indeed He has power over everything" Surah Fussilat, verse no. (39).

"If you have any doubt, O men, about being raised to life again, (remember) that We created you from dust (clay), then a drop of semen, then an embryo, then a chewed up lump of flesh shaped and shapeless, that We may reveal (the various steps) to you. We keep what We please in the womb for a certain time, then you come out as a child, then reach the prime of age. Some of you die, some reach the age of dotage when they forget what they knew, having known it once. You see the soil all withered, then We send down rain upon it, and it bestirs itself, swells, and brings forth every kind of beauteous verdure" Surah Al Hajj, verse no. (5).

"He (God) created man of fermented clay dried tinkling hard like earthenware" Surah AlRahman, verse no. (14).

"Let man consider what he was made of: God was created of spurting water Issuing from (the pelvis) between the backbone and the ribs. God has certain power to bring him back (from the dead)" Surah Al-Tareq, verse no. (5-8).

"Man, We fashioned from fermented clay dried tingling hard" Surah Al-Hijr, verse no. (26).

"Does not man see, We created him from a drop of semen? Even then he becomes an open contender" Surah Yaseen, verse no. (17).

"Say: "Travel on the earth and see how He originated creation. Then (you will know) how God will raise the last raising (of the dead). Surely God has power over everything" Surah AlAnkabut, verse no. (20).

"God produced you from the soil like a vegetable growth; He will then return you back to it, and bring you out again" Surah Noah, verses from 17 to 18 .

"WAS THERE NOT a time in the life of man when he was not even a mentionable thing? Verily, We created man from a sperm yoked (to the ovum) to bring out his real substance, then gave him hearing and sight" Surah Al-Insaan, verses from 1 to 2 .

"There is not a thing that moves on the earth, no bird that flies on its wings, but has a community of its own like yours. There is nothing that, We 
have left out from recording. Then they will all be gathered before their Lord" Surah Al-An'am, verse no. (38).

"There is not a creature that moves on the earth whose nourishment is not provided by God, whose place of sojourning and depositing is not known to Him. All things conform to a manifest law" Surah Hood, verse no. (6).

"He (God) knows whatever goes into the earth and whatsoever issues from it, whatsoever comes down from the sky, and whatsoever goes up to it. He is all-merciful, all-forgiving" Surah Saba (Sheba), verse no. (2).

"Do they not see that, We drive the rain towards a land that is dry, then grow grain from it which their cattle and they themselves eat? Will they not see even then?" Surah Al-Sajda, verse no. (27).

"It is God who created several skies, and as many earths. The commandment is sent down among them so that you may know that God has power over everything, and everything is held within the knowledge of God" Surah Al-Thalaq, verse no. (12).

"On the earth are tracts adjoining one another, and vineyards, fields of corn and date-palm trees, some forked, some with single trunks, yet all irrigated by the self-same water, though We make some more excellent than the others in fruit. There are sure signs in them for those who understand" Surah Al-Ra'd, verse no. (4).

Therefore, the stages of human creation can be followed in different verses of the Quran through collecting these verses together; then we can draw the complete portrait for these stages. These verses include Surah Al-Mo'menon (the Believers), verses (12 - 16), Surah Al Hajj, Ayah (5), Surah Hood, Ayah (6), Surah Al-Insaan, Ayah (1-2), Surah Al-Rahman, Ayah (14), Surah AlAnkabut, Ayah (20), etc. These steps include the creation Man from clay, spurting water, a drop of semen, the sperm fashioned into an embryo, the embryo fashioned into a shapeless lump of flesh, then from the lump of flesh, fashioned bones, then clothed the bones with flesh and then created the consanguinity and affinity. On the other hand, many recent studies have focused on water and soil and their role in human creation (e.g., Zahran and Willis 2009; Parvaiz 2015; Aboul-Enein 2016; Davids and Waghid 2016; Tarighat-Esfanjani and Namazi 2016; Raju and Manasi 2017; Raju et al. 2017; Zakariah et al. 2017).
The Quran generally clarifies the relationships between man and the universe in five main rules: (1) - This relationship should lead to the development, utilization and subjugation for men's benefit and for the fulfillment of their needs.

(2) - This relationship also includes meditation on and contemplation and exploration of the universe and what it contains.

(3) - Man is only a mere manager of the earth and not a proprietor, a beneficiary and not a disposer or ordained. This man has been granted inheritance to manage and utilize the earth for his benefit and for the fulfillment of his needs. Man, therefore, has to keep, maintain and preserve it honestly and has to act within the limits dedicated by honesty.

(4) - God has granted all people of this planet the inheritance of all sources, of life and resources of nature. Thus, the utilization and sustainable use of these resources is the right and privilege of all people. Hence, man should take every precaution to ensure the interests and rights of all others since they are equal partners on earth. Similarly, man should not regard such ownership as restricted to one generation. It is a joint ownership in which each generation uses and makes the best use of nature, according to its needs without disrupting the interests of future generations.

(5) - All religions (Islam, Christianity, Judaism, Buddhism etc.) consider that the environment is the source of life and the depot of resources of nature; accordingly we must protect, conserve and construct and develop its assets and prohibit their abuse and destruction according to Zahran and Willis (2009).

Therefore, it could be concluded that several Quranic verses confirm that Allah created humans (Man) from water and clay. So, common elements can be found in both the soil (clay) and human bodies. Hence, the nutrition of humans should start with plants cultivated in soils.

\section{Conclusion}

The soil is the real treasure not only for the agriculture, but also for human and the environment. It is the main source for our food, feed, fibre and fuel. It has been demonstrated that soil contains the same elements that exist in the human body and plants as well. The creation of 
humans from soil or clay has been mentioned in the Quran. All details about this creation were mentioned also in the Quran. So, the soil has a holy position in all ages and eras and its protection as well as conservation is needed.

\section{Acknowledgments}

The authors thank the outstanding contribution of Prof. Eric C. Brevik (Department of Natural Sciences, Dickinson State University, Dickinson, ND, USA) for his great support and revising the manuscript. The authors also acknowledge the support from the country of Hungary through the project "EFOP-3.6.2-16-2017-00001" Research of complex rural economic and sustainable development, elaboration of its service networks in the Carpathian basin.

\section{References}

Alshaal T, H El-Ramady, N Elhawat, S El-Nahrawy, A Omara, T Elsakhawy, A Ghazi, MH Abbas, IM Farid, N Abdalla, M Fári, É Domokos-Szabolcsy (2019). Soil Health and Its Biology. In: H. ElRamady et al. (eds.), The Soils of Egypt, World Soils Book Series, https://doi.org/10.1007/978-3319-95516-2_10, Springer Nature Switzerland AG

Andrea F, C Bini, S Amaducci (2018) Soil and ecosystem services: Current knowledge and evidences from Italian case studies. Applied Soil Ecology, 123, 693-698.

Balks MR and D Zabowski (2016) Soils and Humans. In: Balks MR and D Zabowski, Celebrating Soil Discovering Soils and Landscapes. pp: 165-191. Springer Cham Nature Switzerland AG. https://doi. org/10.1007/978-3-319-32684-9_8

Baude M, BC Meyer, M Schindewolf (2019) Land use change in an agricultural landscape causing degradation of soil based ecosystem services. Science of The Total Environment, 659, 1526-1536.

Baveye P, JBaveye, JM Gowdy (2016) Soil “Ecosystem” Services and Natural Capital: Critical Appraisal of Research on Uncertain Ground. License CC BY 4.0. DOI:10.3389/fenvs.2016.00041

Brevik E. C. (2013b) Climate change, soils, and human health. In: Brevik, E. C. and Burgess, L. C., Boca Raton (eds.) Soils and Human Health. FL, USA, CRC Press, 345-383.

Brevik E. C. and L. C. Burgess (2012) Soils and Human Health. CRC Press

Brevik E. C. and L. C. Burgess (2014) The Influence

Env. Biodiv. Soil Security Vol. 3 (2019) of Soils on Human Health. Nature Education Knowledge 5(12), 1 http://www.nature.com/ scitable/knowledge/library/the-influenceof-soilson-human-health-127878980

Brevik E. C. and T. J. Sauer (2015).The past, present, and future of soils and human health studies. Soil, 1, 35-46. DOI: 10.5194/soil-1-35-2015

Brevik E. C., J. J. Steffan, L. C. Burgess and A. Cerdà (2017) Links Between Soil Security and the Influence of Soil on Human Health. In: D.J. Field et al. (eds.), Global Soil Security, Progress in Soil Science Series, DOI: 10.1007/978-3-31943394-3_24, pp: 261 - 274. Springer International Publishing Switzerland

Brevik EC, L Pereg, P Pereira, JJ Steffan, CI Gedeon (2019) Shelter, clothing, and fuel: Often overlooked links between soils, ecosystem services, and human health. Science of The Total Environment, 651, Part 1, 134-142.

Brevik, E. C. (2013a) Soils and human health - an overview. In: Brevik, E. C. and Burgess, L. C (eds.). Soils and Human Health. Boca Raton, FL, USA, CRC Press, 29-56.

Brevik, EC L Pereg, JJ Steffan, LC Burgess (2018) Soil ecosystem services and human health. Current Opinion in Environmental Science \& Health, 5, 87 92.

Brevik, Eric C., J. A. Homburg and J. A. Sandor (2018) Soils, climate, and ancient civilizations. Developments in Soil Science, 35, 1-28. https://doi. org/10.1016/B978-0-444-63865-6.00001-6

Carré F, J Caudeville, R Bonnard, V Bert, P Boucard, M Ramel (2017) Soil Contamination and Human Health: A Major Challenge for Global Soil Security. D.J. Field et al. (eds.), Global Soil Security, Progress in Soil Science, DOI 10.1007/978-3-31943394-3_25, pp: 275 - 295. Springer International Publishing Switzerland

Combs Jr, GF (2005) Geological impacts on nutrition. In: Selinus, O. (eds.). Essentials of Medical Geology, (Amsterdam: Elsevier, 2005) pp: 161177.

El-Ramady H, T Alshaal, T Elsakhawy, A Omara, N Abdalla, Eric C. Brevik (2019) Soils and Humans. In: H. El-Ramady et al. (eds.), The Soils of Egypt, World Soils Book Series, https://doi. org/10.1007/978-3-319-95516-2_12, Springer Nature Switzerland AG 
Hanlon P, R Madel, K Olson-Sawyer, K Rabin, J Rose (2013) Food, Water, and Energy: Know The Nexus. Grace Communications Foundation, 31 pp.

Kathpalia R, SC Bhatla (2018). Plant Mineral Nutrition. In: Bhatla and Lal (Eds.), Plant Physiology, Development and Metabolism. pp 37-81, Springer Nature Singapore Pte Ltd.

La Notte A, S Vallecillo, A Marques, J Maes (2019). Beyond the economic boundaries to account for ecosystem services. Ecosystem Services, 35, 116129.

Lal R (2013a)The Nexus of Soil, Water, and Waste. Lecture Series \#1 UNU-FLORES, Dresden, Germany.

Lal R (2013b) Climate-strategic agriculture and the water-soil-waste nexus. J Plant Nutr Soil Sci. 176(4), 479-93.

Lal R, RH Mohtar, AT Assi, R Ray, H Baybil, M Jahn (2017) Soil as a Basic Nexus Tool: Soils at the Center of the Food-Energy-Water Nexus. Curr Sustainable Renewable Energy Rep 4, 117-129. DOI 10.1007/s40518-017-0082-4

Lal R. (2005) Human Society and Soil. In: Lal (ed.) Encyclopedia of Soil Science, DOI: 10.1081/E-ESS-120042700, Taylor \& Francis. Pp: $838-841$

Lizaga I, L Quijano, L Gaspar, MC Ramos, A Navas (2019) Linking land use changes to variation in soil properties in a Mediterranean mountain agroecosystem. CATENA, 172, 516-527

Meena MD, RK Yadav, B Narjary, G Yadav, PC Moharana (2019) Municipal solid waste (MSW): Strategies to improve salt affected soil sustainability: A review. Waste Management, 84, 38-53

Natasha, M Shahid, NK Niazi, S Khalid, B Murtaza, I Bibi, MI Rashid (2018) A critical review of selenium biogeochemical behavior in soilplant system with an inference to human health. Environmental Pollution 234, 915-934.

Nieder R, DK Benbi, FX Reichl (2018a) Soil Components and Human Health. https://doi. org/10.1007/978-94-024-1222-2, Springer Science + Business Media B.V.
Nieder R, DK Benbi, FX Reichl (2018b) Macro- and Secondary Elements and Their Role in Human Health. In: R. Nieder et al., Soil Components and Human Health, https://doi.org/10.1007/978-94024-1222-2_6, Springer Science + Business Media B.V.

Ondrasek G, HB Begić, M Zovko, L Filipović, Z Rengel (2019) Biogeochemistry of soil organic matter in agroecosystems \& environmental implications. Science of The Total Environment 658, 1559-1573

Pavan ALR, AR Ometto (2018) Ecosystem Services in Life Cycle Assessment: A novel conceptual framework for soil. Science of The Total Environment, 643, 1337-1347.

Pereira P, I Bogunovic, M Muñoz-Rojas, EC Brevik (2018) Soil ecosystem services, sustainability, valuation and management. Current Opinion in Environmental Science \& Health, 5, 7-13.

Singh A (2019) Environmental problems of salinization and poor drainage in irrigated areas: Management through the mathematical models. Journal of Cleaner Production, 206, 572-579.

Sullivan P (2017) Water-Energy-Food Security Nexus in the Arab Region: Thoughts and Policy Options. In: K. Amer et al. (eds.), The Water, Energy, and Food Security Nexus in the Arab Region, Water Security in a New World, DOI 10.1007/978-3-31948408-2_8, Springer International Publishing AG

Tecon R and D Or (2017) Biophysical processes supporting the diversity of microbial life in soil. FEMS Microbiology Reviews, 41 (5), 599-623. https://doi.org/10.1093/femsre/fux039

Winiwarter V. (2014) Environmental History of Soils. In: M. Agnoletti and S. Neri Serneri (eds.), The Basic Environmental History, Environmental History 4, DOI: 10.1007/978-3-319-09180-8_3, Springer International Publishing Switzerland

Zahran M. A. and A. J. Willis (2009) The Vegetation of Egypt. The $2^{\text {nd }}$ Edition, Plant and Vegetation Series Vol. 2. Springer Netherlands, DOI: 10.1007/978-14020-8756-1

(Received 31/1/2019; accepted 13/2/2019) 